International Journal of Hiology, Pharmacy and Allied Sciences (IJBPAS) 'A Bridge Betueen Caboratory and QRendor'

WWW.iibpas.com

ANTIBACTERIAL AND ANTICANCER ACTIVITY OF CRUDE SECONDARY METABOLITES OF ANTAGONISTIC BACTERIAL STRAIN PSEUDOMONAS SP-KA2 ISOLATED FROM MARINE SOIL

\title{
NAGOORAN $\mathbf{V}^{1}$, KUMAR $\mathrm{D}^{1}$ AND KANDASAMY $\mathrm{S}^{2 *}$
}

1: Ph. D Research Scholar, Department of Microbiology, Faculty of Science, Annamalai University, Annamalainagar, Chidambaram, Tamilnadu, India- 608002

2: Assitant Professor, Department of Microbiology, Faculty of Science, Annamalai

University, Annamalainagar, Chidambaram, Tamilnadu, India- 608002

*Corresponding Author: Dr. Sivasubramani Kandasamy: E Mail: sivasubramanik@gmail.com Received 26 ${ }^{\text {th }}$ April 2020; Revised $20^{\text {th }}$ May 2020; Accepted $26^{\text {th }}$ June 2020; Available online $1^{\text {st }}$ Dec. 2020 https://doi.org/10.31032/IJBPAS/2020/9.12.5644

ABSTRACT

Marine microbes are rich sources for various types of bioactive compounds. In the present study, the effective antagonistic bacterial strain KA2 was isolated from soil samples collected from the coastal region of Karaikal seashore. The isolated bacterial strain was genomically identified as Pseudomonas sp. The crude secondary metabolite extract (CSME) from the strain was extracted using ethanol and examined for its chemical composition. Further, the CSME was analyzed for their antibacterial and antioxidant activity. The anticancer activity of CSME of KA2 against human oral squamous carcinoma KB cell line was analyzed by MTT assay. The results showed that the CSME of KA2 exhibited effective antimicrobial activity against selected gram-positive and gram-negative bacterial pathogens. Further, showed effective DPPH radical scavenging activity in concentration established way. Moreover, the CSME of KA2 exhibited effective anticancer activity against both tested cancer cell lines with the IC50 value of $101.49 \pm 2.15 \mu \mathrm{g} / \mathrm{mL}$. Therefore, the secondary metabolites of strain Pseudomonas sp KA2 could be used for effective antibacterial and anticancer treatment after the proper clinical and pharmacological trial.

Keywords: Pseudomonas sp, Gram-positive, Anticancer, Oral cancer 


\section{INTRODUCTION}

The increasing number of infectious diseases is an emerging challenge in the modern world. Therefore, there is a need for finding new and effective drugs as an alternative for available drugs. The limited success of strategies such as combinatorial chemistry in providing new agents indicates an uncertain forecast for further antimicrobial therapy [1]. However, the majority of natural bioactive compounds has been isolated from terrestrial organisms, in the last few decades abundantbiologically active compounds have been isolated from marine bacteria. For the first time, in 1947, Rosenfeld and Zobell reported that marine bacteria produce antimicrobial substances [2]. Numerous biological compounds with varying types of biological action, such as antioxidant, anti-microbial, anti-cancer, anti-proliferative, cytotoxic compounds as well as antibiotic properties have been isolated from marine sources. The marine environment is an unexplored source for isolation of new microbes that are effective producers of biologically active secondary metabolites.

Currently, various bioactive compounds from marine microorganisms have been reported, including active compound Pyron from Pseudomonas [3], Loloatin from Bacillus [4], Tiomarinol from
Altromonas [5], Marinopyrroles from Streptomyces [6], Agrochelin from Agrobacterium [7], Koromicin from Pseudoalteromonas [8] and Pelagiomicin from Pelagiobacter variabilis [9] and so on. The present study was designed to isolate the antagonistic marine bacteria from soil samples collected from the seashore of Karaikal. And also, aimed to study the antibacterial and anticancer activity of secondary metabolites extracted from the isolated antagonistic bacterial strain.

\section{MATERIALS AND METHODS}

\section{Sample collection}

The east coast marine region of Karaikal $\left(10^{\circ} 55^{\prime} 05.4^{\prime \prime} \mathrm{N} \quad 79^{\circ} 51^{\prime} 12.8^{\prime \prime} \mathrm{E}\right)$ in south Indian state of Tamil Nadu was selected as a sampling location for isolation of antagonistic bacteria. The soil sample was collected from seashore region of Karaikal $\left(10^{\circ} 55^{\prime} 05.4^{\prime \prime} \mathrm{N} \quad 79^{\circ} 51^{\prime} 12.8^{\prime \prime} \mathrm{E}\right)$, a town of the Indian Union Territory of Puducherry, India. Approximately 10 to 30 $\mathrm{g}$ of soil samples were collected from the selected sampling location in sterile plastic bags in the depth of $5-10 \mathrm{~cm}$ using sterile steel cooper. The soil samples were sieved through a $0.5 \mathrm{~mm}$ sieve to remove stones and plant residues [10]. Sieved soil samples were immediately transferred into the laboratory and stored under refrigerator condition for further use. 


\section{Isolation of marine bacteria}

For the isolation of bacteria from collected soil samples, the dilution spread plate technique [11] was used. Soil sample weighing $1 \mathrm{~g}$ was serially diluted in $10 \mathrm{ml}$ of $50 \%$ seawater $(1: 1 \mathrm{v} / \mathrm{v}$ seawater $(30 \mathrm{ppt})$ : distilled water) up to $10^{-5}$ dilution. $0.1 \mathrm{~mL}$ of sample was from $10^{-5}$ dilution was transferred and spread on the Nutrient agar medium, and the plates were incubated. After incubation, plates were regularly examined to verify the growth of marine bacteria and the total number of bacterial colonies was counted by microbiological colony counter. The morphologically distinct colonies were selected, isolated and purified by standard microbiological plating and streaking methods. Accordingly, four morphologically distinct bacterial colonies were selected and purified. The purified bacterial isolates were subjected to microscopic analysis and deposited at the Microbiology Laboratory. Bacterial strains have been stored in test tubes containing NA slants. The subcultures were made every month.

\section{Collection of test bacterial pathogens}

A total of five human pathogenic bacterial cultures Escherichia coli (MTCC1258), Klebsiella pneumoniae (MTCC109), Staphylococcus aureus (MTCC6908), Streptococcus pneumoniae (MTCC 5542), Staphylococcus epidermidis (MTCC- 2639) were obtained from the
Microbial Type Culture Collection (MTCC), Chandigarh, India for the study.

\section{Screening for antagonistic activity}

The antagonistic activity of isolated bacterial was tested against selected bacterial pathogens by Cross streaking method (CSM) [12]. Muller-Hinton agar (MHM) plates were prepared and inoculated with test bacterial cultures was a streak in the full Petri dish and cross streak in the isolated marine bacteria after that incubated at $37^{\circ} \mathrm{C}$ for 24 hours. This was done to provide enough time for the active organism to produce the metabolites, which will diffuse into the agar medium [13].

\section{Identification of potential antagonistic} bacteria

The genomic DNA of selected antagonistic bacteria KA2 was isolated using a total DNA extraction kit (OMEGA BioTek, Norcross, GA, USA) according to the manufacturer's instructions. After genomic DNA isolation, the DNA was amplified at the $16 \mathrm{~S}$ rRNA region using universal primers $27 \mathrm{~F} \quad$ (50AGAGTtTGAtCCTGGCTCAG-30) and 1492R (50- GGTTACCTTGTTACGACTT-30) using polymerase chain reaction (PCR). The obtained nucleotide sequences of the strain were deposited to GenBank (Ass.No: MW281765). Using the NCBI database, the nucleotide sequences of strain was compared with known sequences and the 
phylogenic tree was created using a neighbour-joining algorithm (MEGA 6.0).

\section{Extraction of secondary metabolites}

The bacterial isolate KA2 was selected for further study. The inoculum of selected bacterial isolatewas prepared by transferring bacterial culture into a $2000 \mathrm{~mL}$ conical flask containing 1000 $\mathrm{mL}$ of Nutrient Broth medium containing optimized nutrient levels. Inoculated flasks were incubated on a shaker at 200 rpm for 48 hours at $30^{\circ} \mathrm{C}$ temperature range. After incubation, the culture broth was centrifuged at $10,000 \mathrm{rpm}$ for 20 minutes, then the supernatant was separated carefully. Further, cold absolute ethanol was added to the supernatant in a ratio of $1: 3(\mathrm{v} / \mathrm{v})$ and kept at $4{ }^{\circ} \mathrm{C}$ for 24 hours for precipitation of secondary metabolites. The precipitates were recovered by centrifugation and purified by washing with Mille $\mathrm{Q}$ water and secondary metabolites pellets were dried at $60{ }^{\circ} \mathrm{C}$.

\section{Assessment of Chemical composition}

\section{Phenolic Content Assay}

Total phenolic content of the CSME was measured using Folin-Ciocalteu reagent as described by [14] with minor changes. Briefly, extract solutions (10 $\mathrm{mg} / \mathrm{ml} ; 5 \mu \mathrm{l})$ were mixed with $37.5 \mu \mathrm{l}$ of Folin-Ciocalteu reagent and incubated at room temperature for $5 \mathrm{~min}$. To the reaction mixture, $37.5 \mu 1$ of $6 \%(\mathrm{w} / \mathrm{v})$ sodium carbonate was added and further incubated at $25{ }^{\circ} \mathrm{C}$ for $90 \mathrm{~min}$. Absorbance was measured at $725 \mathrm{~nm}$ using Nano-Drop 2000C (Thermo Fischer Scientific). The total phenolic content was calculated against gallic acid $(0.0-110 \mu \mathrm{g} / \mathrm{ml})$ standard curve.

\section{Flavonoid Content Assay}

Total flavonoid content of the CSME was measured using aluminium chloride colourimetric method, as described earlier [15], with some modifications. Freshly prepared extract solutions (10 $\mathrm{mg} / \mathrm{ml}$ ) were mixed with $10 \mu \mathrm{l}$ of $10 \%$ aluminium chloride, $10 \mu \mathrm{l}$ of $1 \mathrm{M}$ potassium acetate and $160 \mu \mathrm{l}$ of deionized water, followed by incubation at room temperature for $30 \mathrm{~min}$. Quercetin and DMSO were included as controls. The absorbance of the reaction mixture was determined at $405 \mathrm{~nm}$ using NanoDrop 2000C (Thermo Fischer Scientific). A calibration curve was plotted using quercetin as standard (at final concentrations $1.85-50 \mu \mathrm{g} / \mathrm{ml}$ ).

\section{Assessment of Antibacterial activity}

In Disc-diffusion assay (KirbyBauer Method), the test bacterial cultures were swabbed over the Muller Hinton agar. Then the discs loaded with different concentration of crude secondary metabolite extract (CSME) obtained from the antagonistic bacteria $(100,200,300$, $400 \mu \mathrm{g}$ ) and positive control (Standard 
antibiotic Erythromycin $20 \mu \mathrm{g})$, and placed over the agar medium. All plates were incubated at $37{ }^{\circ} \mathrm{C}$ for 24 hours and examined for a zone of inhibition. The diameter of the growth inhibition was recordedby measuring the zone of inhibition.

\section{Determination of Minimal Inhibitory Concentration (MIC)}

The MIC of CSNE of KA2 strain was determined by two fold dilution method. Briefly, $100 \mu \mathrm{L}$ Muller-Hinton broth (Himedia) and various concentrated bacterial metabolites were prepared and transferred to 90 well plates to obtain dilutions of the active extract from 43.7 to $700 \mathrm{mg} / \mathrm{ml}$. Then, $10 \mu \mathrm{L}$ of the test organisms were added to the new culture (final concentration of $1 \times 10^{6} \mathrm{CFU} / \mathrm{ml}$ ). The plates were incubated for $24 \mathrm{~h}$ at 37 ${ }^{\circ} \mathrm{C}$. The microbes were defined as the lowest concentration of the extract to control the visible growth of the tested organisms.

\section{Antioxidant activity}

\section{DPPH free radical- scavenging activity}

The antioxidant activity of CSME of KA2 was determined by DPPH free radical assay. The DPPH radical scavenging activity was measured according to the method described by Brand-Williams et al., [16]. The sample was reacted with the stable DPPH radical in an ethanol solution. The reaction mixture is composed of adding $0.5 \mathrm{~mL}$ of sample, 3 $\mathrm{mL}$ of absolute ethanol and $0.3 \mathrm{~mL}$ of DPPH radical solution $0.5 \mathrm{mM}$ in methanol. DPPH reacts with an antioxidant compound the colour change will take place. The colour changes were perused [Absorbance (Abs)] at $517 \mathrm{~nm}$. The blend of ethanol $(3.3 \mathrm{~mL})$ and sample $(0.5 \mathrm{~mL})$ serve as blank. The control solution of Ascorbic acid was put together by mixing ethanol $(3.5 \mathrm{~mL})$ and $\mathrm{DPPH}$ radical solution. The scavenging activity percentage $(\mathrm{AA} \%)$ was calculated according to the following formula.

Radical scavenging activity (AA\%)

$$
=\frac{\text { Abs control }- \text { Abs sample }}{\text { Abs control }} \times 100
$$

\section{Cancer cell culture}

The human oral squamous carcinoma $\mathrm{KB}$ cell cells were obtained from the National Centre For Cell Science (NCCS), Pune, India. Cells were cultured and maintained in DMEM and incubated at $37{ }^{\circ} \mathrm{C}$ in a $5 \% \mathrm{CO}_{2}$ and $95 \%$ air incubation (humidified condition). Before treatment to the cells, the synthesized $\mathrm{ZnO}$ NPs completely dissolved in dimethyl sulfoxide (DMSO).

\section{Cytotoxicity of CSME of KA2 on KB}

The cytotoxicity of CSME of KA2 on $\mathrm{KB}$ cells was evaluated by employing MTT assay. The KB cells $\left(1 \times 10^{5}\right)$ were seeded in 96 wells plate and grown for 24 $\mathrm{h}$ at the humified incubator condition. After incubation, the cells were exposed 
to different concentrations of CSME (50, $60,70,80,90,100,110,120$ and 130 $\mu \mathrm{g} / \mathrm{mL}$ ) for $24 \mathrm{~h}$ after replacing the old medium with the new medium. Afterwards, the $100 \mu \mathrm{L}$ of MTT reagent (5 $\mathrm{mg} / \mathrm{mL}$ in PBS) was subsequently added into each well, then the plate was kept in dark condition for $4 \mathrm{~h}$. By adding the $100 \mu \mathrm{L}$ of DMSO, the resulting formazan was dissolved. Further, the absorption of dissolved formazan was determined at $595 \mathrm{~nm}$ wavelength using ELIZA plate reader (Tecan Multimode Reader, Austria). The concentrations of the test sample which showed $50 \%$ of cell death was calculated.

\section{RESULTS}

\section{Isolation of marine bacterial strains}

The collected soil sample was serially diluted and inoculated on nutrient plates and incubated. After incubation, $21.67 \pm 1.34 \mathrm{CFU} / \mathrm{g} \times 10^{5}$ colonies were counted on nutrient plates, from that 4 morphologically distinct bacterial colonies were observed and selected for the further study. The selected bacterial strains were named as KA1, KA2, KA3, KA4.

\section{Antagonistic activity of isolated bacterial strains}

The isolated bacterial strains were tested for its antagonistic nature against the test bacterial pathogens. Among the tested bacterial strains, the isolate KA2 showed significant antagonistic activity against the 4 tested bacterial pathogens. Other bacterial strains KA1 and KA3 exhibited significant growth inhibition activity against 2 bacterial pathogens. The isolates KA4 showed growth inhibitory activity against only one bacterial pathogen. The results indicate that the isolate KA2 exhibited significate antagonistic activity over the other bacterial isolates (Figure 1 \& Table 1).

\section{Identification of antagonistic bacteria}

The obtained nucleotide sequence of the isolated antagonistic bacterial strain was compared for the similarity with known sequenced using the BLAST search tool. The obtained sequences showed over $98 \%$ of similarity with the known sequence of Pseudomonas sp. Further, the strain was identified as a genus of Pseudomonas sp. (Figure 2).

\section{Assessment of Chemical composition}

After, extraction of secondary crude metabolic extract from Pseudomonas sp KA2 strain, the CSME was analyzed for total phenol and total flavonoid content. The results indicated the presence of ahigh amount of total flavonoids (198.43 \pm 2.36 $\mu \mathrm{g} / \mathrm{mg})$. The total phenolic content calculated against gallic acid was relatively low $(34.37 \pm 1.40 \mu \mathrm{g} / \mathrm{mg})$.

\section{Antibacterial activity and MIC}

The collected bacterial crude secondary metabolites were examined for 
its antibacterial activity on MHA plates. The crude secondary metabolites of isolate KA2 displayed greater antibacterial activity against all the selected pathogens and the zone of inhibition has varied significantly according to the concentration used. The maximum growth inhibitory activity of crude secondary metabolites of strain KA2 was observed against Staphylococcus aureus followed by Streptococcus pneumoniae, and Escherichia coli. However, the crude secondary metabolites of strain KA2 exhibited lesser inhibitory activity against Staphylococcus epidermidis while compared with other tested bacterial pathogens. The standard antibiotic Ciprofloxacin recorded zone of inhibition ranged from 21 to $26 \mathrm{~mm}$. The MIC values ranged between 43.7 to $350 \mu \mathrm{g} / \mathrm{ml}$ and the lowest MIC value of $87.5 \pm 2.5 \mu \mathrm{g} / \mathrm{ml}$ was recorded against Staphylococcus aureus, Escherichia coli and Streptococcus pneumoniae. The inhibition of Klebsiella pneumonia was started at the concentration of $350.0 \pm 6.4 \mu \mathrm{g} / \mathrm{ml}$ (Table 2 \& Figure 3).

\section{Antioxidant activity of CSME}

The CSME of KA2 showed a concentration established anti-DPPH free radical scavenging activity. The crude secondary metabolites of strain KA2 exhibited the effective DPPH inhibition activity, and the maximum inhibition of $39.76 \pm 1.32 \%$ was observed at $40 \mu \mathrm{g} / \mathrm{ml}$ concentration, which is considerably lesser than the inhibitory activity of 40 $\mu \mathrm{g} / \mathrm{ml}$ of standard (Figure 4).

\section{Cytotoxicity of CSME on KB cells}

The cytotoxicity of CSME on KB cells was studied by establishing the MTT assay. The results exhibited that the concentration-dependent cytotoxicity on $\mathrm{KB}$ cells was demonstrated by CSME of KA2. The $50 \%$ inhibition of cell growth (IC50) was calculated as 101.49 \pm 2.15 $\mu \mathrm{g} / \mathrm{mL}$ (Figure 5).

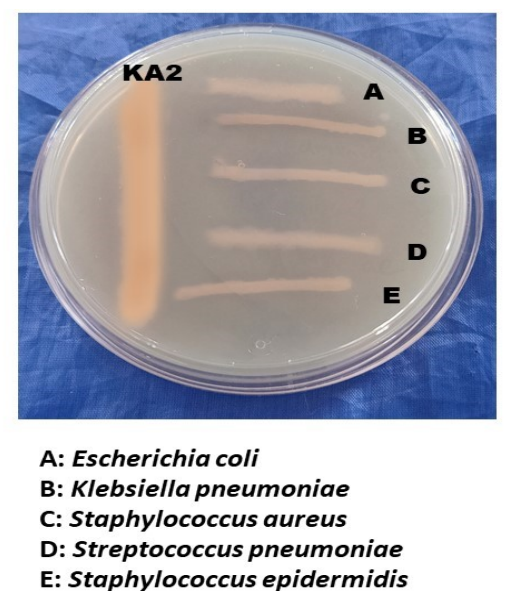

Figure 1: Antagonistic activity of Pseudomonas sp KA2 bacterial strain against teste bacterial pathogens 
Table 1: Antagonistic activity of bacterial strains isolated from collected soil samples

\begin{tabular}{|c|c|c|c|c|c|}
\hline \multirow{2}{*}{$\begin{array}{c}\text { Bacterial } \\
\text { strains }\end{array}$} & \multicolumn{5}{|c|}{ Test bacterial pathogens } \\
\cline { 2 - 6 } & $\begin{array}{c}\text { Escherichia } \\
\text { coli }\end{array}$ & $\begin{array}{c}\text { Klebsiella } \\
\text { pneumonia }\end{array}$ & $\begin{array}{c}\text { Staphylococcus } \\
\text { aureus }\end{array}$ & $\begin{array}{c}\text { Streptococcus } \\
\text { pneumoniae }\end{array}$ & $\begin{array}{c}\text { Staphylococcus } \\
\text { epidermidis }\end{array}$ \\
\hline KA1 & - & + & - & + & - \\
\hline KA2 & + & + & + & + & - \\
\hline KA3 & + & - & + & - & - \\
\hline KA4 & + & - & + & - & - \\
\hline
\end{tabular}

Note: +; positive, -; negative

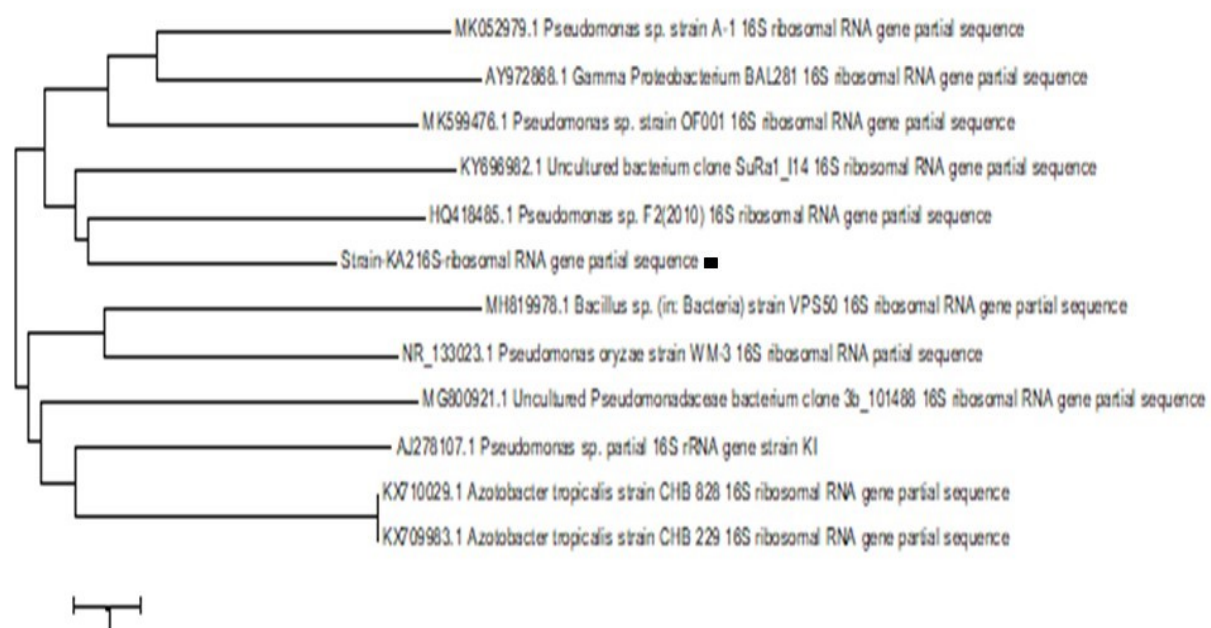

Figure 2: Phylogenetic classifications of isolated antagonistic bacterial stain. The tree was constructed by the neighbour-joining method with known bacterial sequences using MEGA 6.0

Table 2: Antibacterial and MIC activity of crude secondary metabolites of Pseudomonas spKA2 strain against bacterial pathogens

\begin{tabular}{|c|c|c|c|c|c|c|}
\hline \multirow{2}{*}{$\begin{array}{c}\text { Test bacterial } \\
\text { pathogens }\end{array}$} & \multicolumn{6}{|c|}{ Zone of inhibition (mm) } \\
\hline & $100 \mu \mathrm{g}$ & $200 \mu \mathrm{g}$ & $300 \mu \mathrm{g}$ & $400 \mu \mathrm{g}$ & Erythromycin $(20 \mu \mathrm{g})$ & MIC ( $\mu g)$ \\
\hline $\begin{array}{c}\text { Klebsiella } \\
\text { pneumoniae }\end{array}$ & - & $8.65 \pm 0.54$ & $10.49 \pm .67$ & $12.78 \pm 0.54$ & $24.57 \pm 0.65$ & $175.0 \pm 6.4$ \\
\hline $\begin{array}{c}\text { Staphylococcus } \\
\text { aureus }\end{array}$ & $10.76 \pm 0.76$ & $12.76 \pm 0.27$ & $15.31 \pm 0.15$ & $19.65 \pm 0.34$ & $23.45 \pm 0.38$ & $43.7 \pm 1.4$ \\
\hline $\begin{array}{c}\text { Streptococcus } \\
\text { pneumoniae }\end{array}$ & $09.36 \pm 0.54$ & $10.85 \pm 0.34$ & $14.34 \pm 0.45$ & $16.76 \pm 0.39$ & $23.68 \pm 0.23$ & $87.5 \pm 1.6$ \\
\hline
\end{tabular}

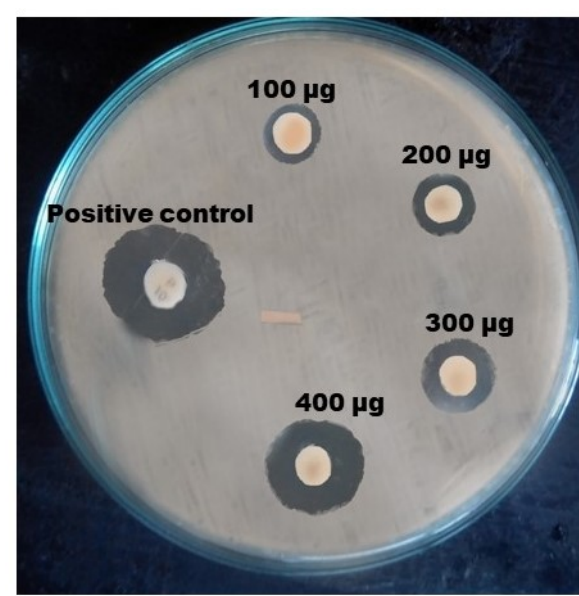

Figure 3: Antibacterial activity of crude secondary metabolites of Pseudomonas sp KA2 against Staphylococcus aureus bacterial pathogen on $\mathrm{MH}$ agar plate 


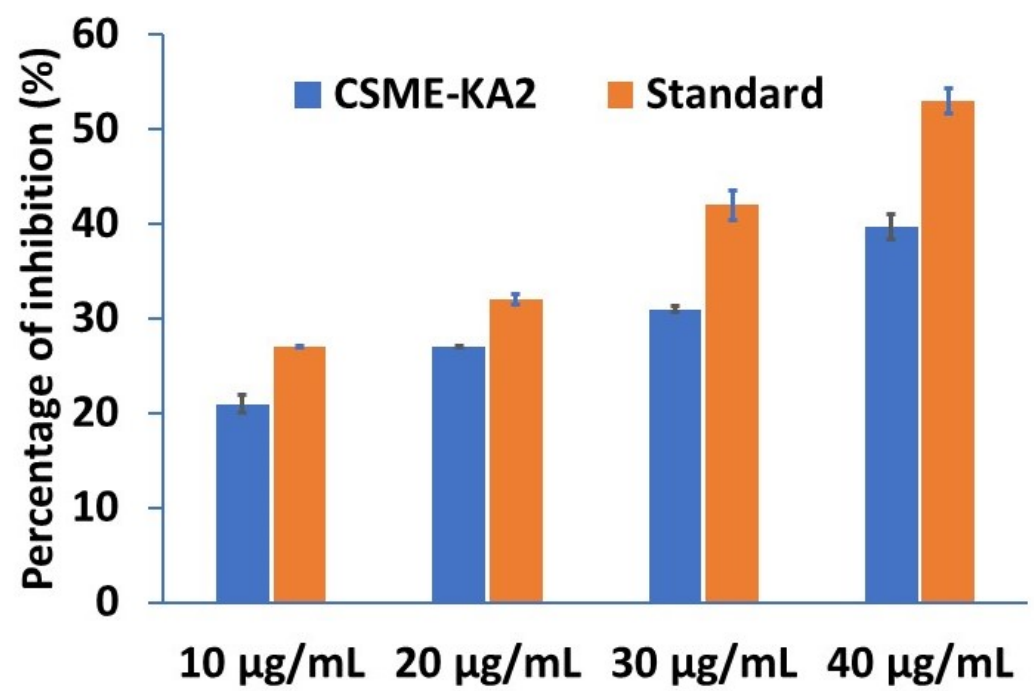

Figure 4: DPPH free radical scavenging activity of crude secondary metabolites of Pseudomonas sp KA2

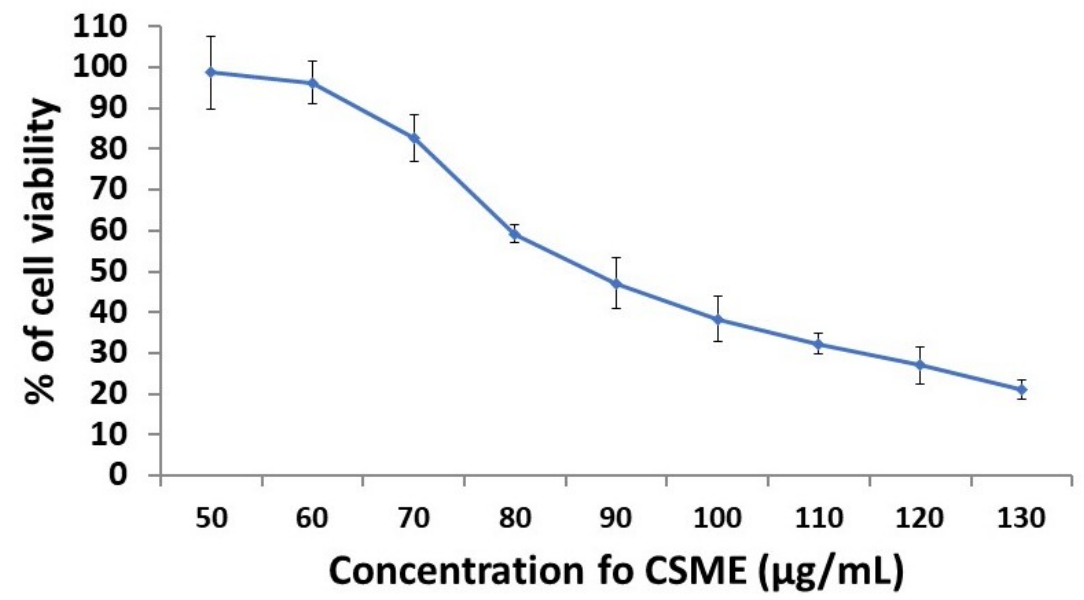

Figure 5: Cytotoxic activity of crude secondary metabolites of Pseudomonas sp KA2 strain against oral squamous carcinoma KB cell

\section{DISCUSSION}

Numerous metabolites from marine microbes showed structurally distinct from their terrestrial counterparts $[\mathbf{1 7}, \mathbf{1 8}]$ and possess extensive biological activities. Recently several studies carried out on the biological activities of secondary metabolites extracted from marine bacterial isolates.Moreover, some reports found that the marine strains of Pseudomonas are a potential source for the biologically active secondary metabolites. In the current study, we isolated the antagonistic Pseudomonas $s p$ along with other antagonistic bacterial strains from the soil sample collected from the seashore of Karaikal. Since Pseudomonas was first described in the $19^{\text {th }}$ century this bacterium has been regarded as a terrestrial or freshwater species. Studies of its existence in marine environments have been restricted to shorelines [19, 20, 21]. Members of the 
genus Pseudomonas are known as a potential source for the biologically active metabolic compounds [22]. Pseudomonas spproduced phenazine which was active against Gram-positive bacteria and actinomycetes with varying antimicrobial activity. In another study [23, 24], extracts of Pseudomonas spand Pseudomonas chlororaphis 449, have been reported for antimicrobial activity against Gram-positive and Gram-negative bacteria [25] reported that the Pseudomonas sp. possess the effective antimicrobial activity against both Gram-positive and negative organisms including MRSA (methicillin-resistant Staphylococcus aureus). In this current study, the secondary metabolic extract of Pseudomonas sp KA2 strain showed a wider range of antibacterial activity against selected gram-positive and gram-negative bacterial pathogens.

Anticancer activity of secondary metabolic extract of Pseudomonas sp KA2 strain was examined on $\mathrm{KB}$ cells. The results suggest that the concentrationdependent cytotoxicity on KB cells. Similarly, the concentration-dependent cytotoxicity on cancer cell lines HeLa, HepG2 and SHSY5Y was exhibited by secondary metabolic extract of Pseudomonas sp BS25 strain [26]. Recently, several secondary metabolites produced by Pseudomonas sphave been reported to be cytotoxic [27] reported that metabolites extracted from $P$. aeruginosa LN strain can serve as bactericides to control plant diseases in greenhouse. Semipurified extracts of the strain showed antimicrobial effect against Xanthomonas sp [27].

\section{CONCLUSIONS}

The antagonistic bacterial strain Pseudomonas sp KA2 was isolated from soil samples collected Karaikal seashore region. The crude secondary metabolites were extracted from the isolated KA2 stain using ethanol. The extracted crude secondary metabolites exhibited concentration-dependent antibacterial activity and antioxidant activity. Moreover, exhibited effective concentration-dependent cytotoxicity on oral squamous carcinoma KB cell. The obtained results suggest that the crude secondary metabolic extract of antagonistic bacterial strain Pseudomonas sp KA2 possess the effective antibacterial, antioxidant and anticancer activity in invitro condition. Consequently, it could be used for the treatment of infectious disease and oral cancer treatment after proper purification of compound and clinical trial.

\section{ACKNOWLEDGEMENT}

The authors would like to thank YaazhXenomic laboratories, Coimbatore for excellent technical and bioinformatics assistance, and also thanks to Dr. 
Yoganathan Kamaraj for his suggestion and manuscript editing.

\section{REFERENCES}

[1] Magarvey N.A, Keller J.M, Bernan V, Dworkin M, Sherman D.H. Isolation and characterization of novel marinederived Actinomycete taxa rich in bioactive metabolites. Appl Environ Microbiol 2004 70(12): 7520-9.

[2] WanNorhana N, Darah I. Vibrio ruber (S2A1), a marine bacterium that exhibits significant antimicrobial activity. Mal J Microbiology 2005 1(1): 25-30.

[3] Singh M.P, Kong F, Janso J.E, Arias D.A, Suarez P.A, Bernan V.S, et al. Novel -pyrones produced by a marine Pseudomonas sp. F92S91: Taxonomy and biological activities. J Antibiot 2003 56(12): 1033-44.

[4] Tuin AW,Grotenbreg G.M, Spalburg E, de Neeling A.J, Mars- Groenendijk R.H, van der Marel GA, et al. Structural and biological evaluation of some loloatin $\mathrm{C}$ analogues. Bioorg Med Chem 200917 (17): 6233-40.

[5] Gao X, HallD.G. Catalytic asymmetric synthesis of a potent thiomarinol antibiotic. J Am Chem Soc 2005127 (6): 1628-9.

[6] Hughes C.C, Prieto-Davo A, Jensen PR, Fenical W. The Marinopyrroles, antibiotics of an unprecedented structure class from a marine
Streptomyces sp. Org Lett 2008 10(4): 629-31.

[7] Rondon M.R, Ballering K.S, Thomas M.G. Identification and analysis of a siderophore biosynthetic gene cluster from Agrobacterium tumefaciens C58. Microbiol 2004150 (11): 3857-66.

[8] Jang J.H, Kanoh K, Adachi K, Shizuri Y. New dihydrobenzofuran derivative, awajanoran, from marine-derived Acremonium sp. AWA16-1. J Antibiot 2006 59(7): 428-31.

[9] Sabdono A, Radjasa O.K. Antifouling activity of bacteria associated with soft coral Sarcophyton sp. against marine biofilm-forming bacteria. J Coast Develop 2006 10(1): 55-62.

[10]Leslie J.F, Summerell B.A. The Fusarium Laboratory Manual. Blackwell Publishing, Hoboken, 2006 $1-2$.

[11] Warcup J.H. The Soil-Plate Method for Isolation of Fungi from Soil. Nature, $1950166,117-118$.

[12]Lertcanawanichakul M, Sawangnop S.A. comparison of two methods used for measuring the antagonistic activity of Bacillus species Walailak J. Sci. Tech., 2008 5: 161-171.

[13] Waksman selman A, Lechevalier, Hubert A. The Actinomycetes. Vol. III. Antibiotics of Actinomycetes. 1962 8: 430. 
[14] Velioglu Y.S, Mazza G, Gao L.et al. Antioxidant activity and total phenolics in selected fruits, vegetables, and grain products. J. Agric. Food Chem. 1998 46: 4113-4117.

[15] Jafri L, Saleem S, Mirza B. In vitro assessment of antioxidant potential and determination of polyphenolic compounds of Hederanepalensis K. Koch. Arab. J. Chem. 2014 10, S3699S3706.

[16]Brand-Williams W, Cuvelier M.E, Berset C. Use of free radical method to evaluate antioxidant activity. LebensmWiss Technology, 1995 28: 25-30.

[17] Jensen P.R, Fenical W. Strategies for the discovery of secondary metabolites from marine bacteria: Ecological perspectives. Annu. Rev. Microbiol. 1994 48: 559-584.

[18]Feling R.H, Buchanan G.O, Mincer T.J, Kauffman C.A, Jensen P.R, Fenical W, Salinosporamide A. A highly cytotoxic proteasome inhibitor from a novel microbial source, a marine bacterium of the new genus salinospora. Angew. Chem. Int. Ed. Engl. 2003 20: 355-357.

[19] Schroeter J. bereinigedurch Bacteriengebildete Pigmente. In: Cohn F (Ed.) Beitra“gezu“rBiologie der Pflanzen, J. U. Kern's Verlag, Breslau, pp 1872 109-126.
[20]Mates A. The significance of testing for Pseudomonas aeruginosa in recreational seawater beaches. Microbios 1992 71: 89-93.

[21] Papapetropourou M, Rodopoulou G. Occurrence of enteric and non-enteric indicators in coastal waters of southern Greece. Bull Mar Sci 1994 54: 63-70

[22]Mena, K.D, and Gerba, C.P. Risk assessment of Pseudo- monas aeruginosa in water. Reviews of Environmental Contami- nation and Toxicology 2009 201:71-115.

[23] Veselova A, Klein S.H, Bass I.A, Lipasova V.A, Metlitskaia A.Z, Ovadis M.L, Chernin L.S, Khmel, I.A. Quorum sensing systems of regulation synthesis of phenazine antibiotics, and antifungal activity in rhizospheric bacterium Pseudomonas chlororaphis 449. Russ. J. Genet 2008 44: 14001408 .

[24]Mezaache-Aichour S, Guechi A, Nicklin J, Drider D, Prevost H, Strange R.N. Isolation, identification and antimicrobial activity of Pseudomonads isolated from the rhizosphere of potatoes growing in Algeria. J. Plant Pathol2012 94 (1), 89-98.

[25] Charyulu E.M, Sekaran G, Rajakumar G.S, Gnanamani A. Antimicrobial activity of secondary metabolite from marine isolate, Pseudomonas sp. 
against Gram positive and negative bacteria including MRSA. Indian J Exp Biol. 2009 47(12):964-8. PMID: 20329699.

[26] Mushtaq S, Uzair B, Hameed A. et al. In Vitro Cytotoxicity of Secondary Metabolites Extracted from Pseudomonas aeruginosa BS 25 Strain. Arab J Sci Eng 2020 45, 81-94.

[27] Spago F.R, Mauro C.I, Oliveira A.G, et al. Pseudomonas aeruginosa produces secondary metabolites that have biological activity against plant pathogenic Xanthomonas species. Crop Prot. 2014 62, 46-54. 